\title{
TIMOMUL: O CAUZĂ RARĂ DE TUMORĂ MEDIASTINALĂ LA COPIL
}

\author{
Andreea Durlan', Cristina Oana Mărginean², Maria Despina Baghiu', \\ Alina Grama², Emoke Horvath ${ }^{3}$, Mihaela-Ioana Chinceşan ${ }^{2}$ \\ ${ }^{1}$ Clinica I Pediatrie, Spitalul Clinic Județean de Urgență, Târgu Mureş \\ ${ }^{2}$ Disciplina I Pediatrie, Universitatea de Medicină şi Farmacie, Târgu Mureş \\ ${ }^{3}$ Disciplina Anatomie Patologică, Universitatea de Medicină şi Farmacie, Târgu Mureş
}

\begin{abstract}
REZUMAT
Timomul este un neoplasm format din celule epiteliale timice, fiind rar întâlnit la copii. Aproximativ două treimi din tumorile mediastinale sunt asimptomatice la copii, diagnosticul fiind suspicionat în urma efectului de compresie a masei tumorale asupra căilor respiratorii. Prezentăm cazul unui pacient de sex masculin, în vârstă de 7 ani şi 8 luni, care se prezintă în serviciul de urgență acuzând oboseală la eforturi mici/repaus, tuse seacă, dispnee marcată, ortopnee, tahipnee, durere toracică, de unde se transferă de urgență la Clinica de Cardiologie Pediatrică, Tîrgu Mureş, cu diagnosticele: pericardită lichidiană, tamponadă cardiacă şi pleurezie dreaptă. Examenul computer tomografic toracic descrie o masă solidă inomogenă de 100/89/111 mm, la nivelul mediastinului anterior înglobând timusul şi parțial structurile vasculare ale mediastinului mijlociu. Se practică pericardectomie parțială, prelevare de țesut tumoral şi citoreducție tumorală extensivă, examenul histopatologic fiind Timom B3. Se inițiază chimioterapie conform protocolului VENUTA Tymom, urmat de radioterapie adjuvantă, cu remisie clinică şi radiologică. Particularitatea cazului este dată de faptul că timomul este o tumoră rară la vârsta pacientului, creând dificultăți de diagnostic, fiind fără complicații în timpul tratamentului, cu evoluție favorabilă, cu remisie clinică şi radiologică la 1,9 ani.
\end{abstract}

Cuvinte cheie: copil, timom, tumoră mediastinală

\section{INTRODUCERE}

Timusul este o glandă în forma literei H ce ocupă mediastinul anterior, acoperă pericardul şi vasele mari de la baza inimii (1). Tumorile timice sunt formațiunile cel mai frecvent rezecate din mediastin, dar se întâlnesc rar la copiii sub 16 ani (2). Ele sunt localizate frecvent (95\%) în compartimentul anterior al mediastinului, dar au fost întâlnite şi la nivelul gâtului, plămânului sau regiunea hilară stângă $(1,3)$. Celulele epiteliale şi țesuturile stromale ale timusului influențează selecția şi maturarea limfocitelor T, iar dereglarea procesului de selecție a limfocitelor, duce la proliferare celulară anormală. Timomul este o tumoră încapsulată (timoame benigne non invazive), $70 \%$ fiind asociate cu sindroame paraneoplazice, cum ar fi miastenia gravis, anemie aplastică, boli de colagen, pemfigus şi imunodeficiență $(3,4)$. Timomul benign poate să devină extrem de bine vascularizat sau necrotic şi să sângereze, însă poate avea dimensiuni mari şi să fie asimptomatic pentru perioade lungi. Timoamele maligne invadează (metastazează) țesuturile din jur destul de rar - plămân, pericard sau vasele mari de sânge, dar cu consecințe foarte grave. Sindroamele de compresie care implică bronhiile, plămânii sau sindromul de venă cavă superioară, pot să apară de la răspândirea locală a timomului benign, chisturilor timice sau carcinomului timic (3). Simptomele pot să includă dureri toracice, sindrom de venă cavă superioară, dispnee, disfagie şi tuse (4). Imunofenotiparea limfocitelor din sângele periferic relevă un număr absent sau foarte scăzut de celule B şi scăderea numărului absolut de limfocite T CD4+ (2). Tratamentul constă în rezecție chirurgicală, radioterapie postoperatorie şi chimioterapie pentru timomul invaziv, fiind raportat a avea o rată de răspuns favorabil de $70-80 \%(3,4)$. Având în vedere că timomul este de obicei bine încapsulat, timectomia poate să fie curativă în stadiile incipiente. Prognosticul după rezecția chirurgicală variază în funcție de

Adresa de corespondență:

Cristina Oana Mărginean, Universitatea de Medicină şi Farmacie, Str. Gh. Marinescu nr. 38, Târgu Mureş, România

E-mail: marginean.oana@gmail.com 
tipul histologic, invazia regională şi la distanță a tumorii. Rata de supraviețuire asociată cu timomamele încapsulate este de $97 \%$ la 5 ani (6).

\section{PREZENTARE DE CAZ}

Pacient de sex masculin, în vârstă de 7 ani şi 8 luni, din ale cărui antecedente personale patologice menționăm o tuse rară cu debut în urmă cu 2 luni, iar cu o zi anterior internării prezintă tuse seacă, oboseală la eforturi mici/repaus, dispnee marcată, ortopnee, tahipnee, durere toracică. Se prezintă în serviciul de urgență teritorială, unde după efectuarea radiografiei toracice şi ecocardiografiei, se transferă de urgență la Clinica de Cardiologie Pedi- atrică, Tîrgu Mureş, cu diagnosticele de pericardită lichidiană, tamponadă cardiacă şi pleurezie dreaptă care necesită drenaj chirurgical. Întrucât evoluţia pe 24 de ore a fost nefavorabilă, pacientul a fost transferat în Clinica de Chirurgie Cardio-Vasculară. Examenul computer tomografic toracic cu contrast intravenos efectuat descrie o masă solidă inomogenă, cu arii chistice incluse, dezvoltată la nivelul mediastinului anterior înglobând timusul şi parţial structurile vasculare ale mediastinului mijlociu, dimensiune 100/89/111 mm. Masa descrisă amprentează vena cavă superioară, venind în contact cu pericardul, extinzându-se cranial până în dreptul porţiunii superioare a manubriului sternal şi caudal
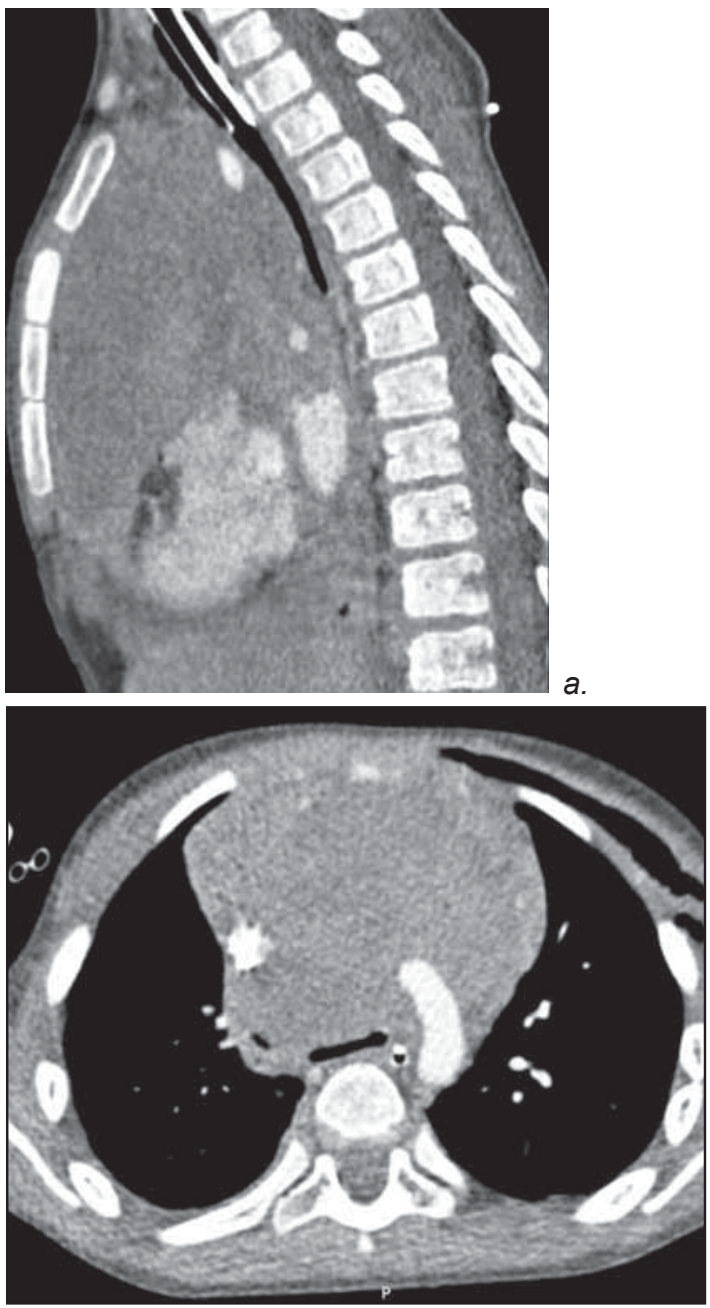

C.
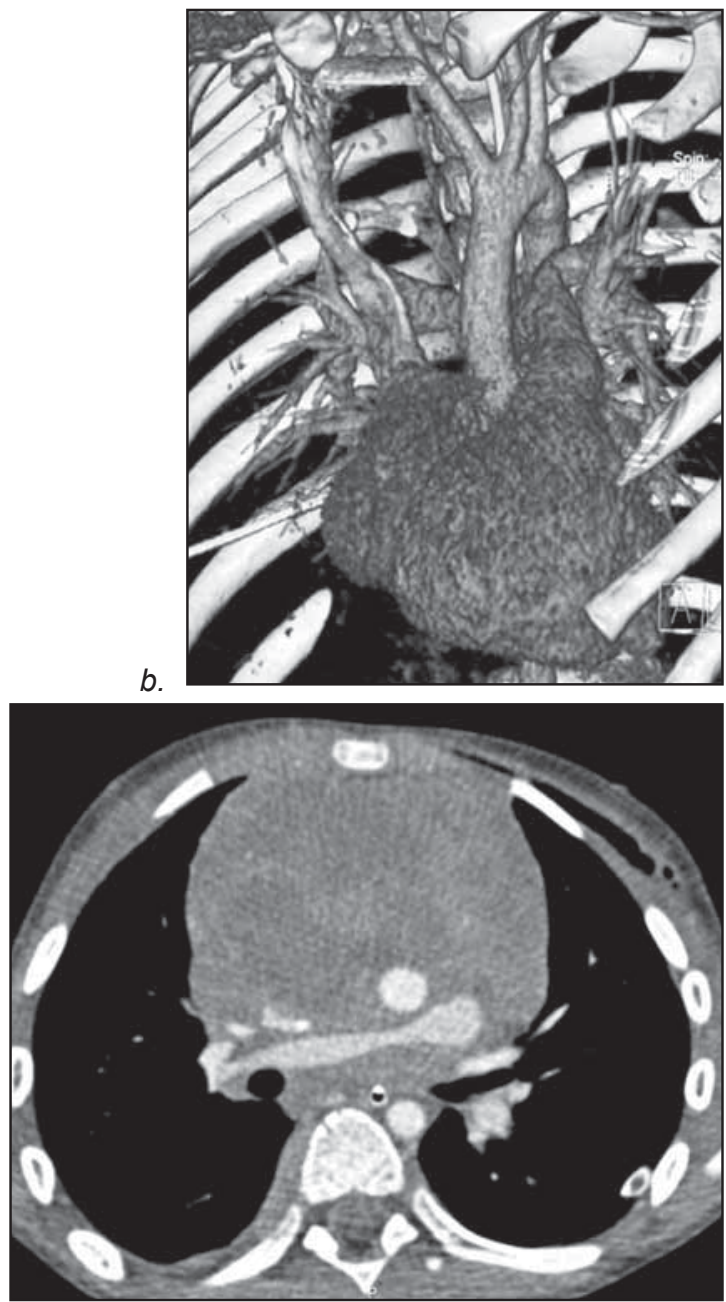

d.

FIGURA 1.

a. Imagine CT de reconstrucție în plan sagital postcontrast iv. - masă voluminoasă de consistență solidă cu iodofilie moderată neomogenă, ce ocupă mediastinul anterior, cu înglobarea şi împingerea marilor vase spre posterior, compresie marcată a traheei;

b. Imagine CT postcontrast iv. (reconstrucție 3D), vedere oblic anterior stâng - evidențierea compresiei şi devierii marilor vase (VCS şi aorta);

c. CT secțiune axială postcontrast iv. - masă cu aspect infiltrativ ce înglobează marile vase cu împingerea lor spre posterior şi traheomalacie;

d. Masă cu aspect infiltrativ ce determină devierea vaselor cu evidențierea compresiei VCS şi a arterei pulmonare drepte. 
la 1,5 cm de diafragm (Fig. 1 a, b, c, d). Se practică pericardectomie parțială, prelevare de țesut tumoral şi citoreducție tumorală extensivă în vederea decomprimării sistemului venos cav superior şi al segmentului arborelui respirator. Fragmentele sunt trimise pentru examen histopatologic.

În ziua a 7-a a bolii, pacientul este transferat in Compartimentul Hemato-oncologie al Clinicii I Pediatrie. Examenul fizic relevă o stare generală alterată, tegumente palide, cicatrice posttoracotomie torace anterior, adenopatii generalizate. Analizele de laborator la internare evidențiază: anemie (Hemoglobina 9,5 g/l); LDH (lactat dehidrogenaza): $1.468 \mathrm{U} / 1$; reactanții de fază acută pozitivi; frotiu periferic cu neutrofile segmentate $74 \%$, polimorfonucleare hipersegmentate; medulogramă cu celularitate normală; lichid cefalorahidian fără modificări; imunogramă în limite normale; Enolaza neuron specifică cu valori crescute $(143,7 \mathrm{ng} / \mathrm{ml})$; Acid vanilmandelic/urină 24 ore normal, Feritina crescută $(191 \mathrm{ng} / \mathrm{ml})$ şi Cupremia în limite normale. S-au efectuat investigații imagistice (CT torace-abdomen-pelvis cu contrast iv.) ce evidențiază masă densă restantă în mediastinul anterior (verosimil țesut timic), ganglioni localizați în loja Baretty de $23 \mathrm{~mm}$, nu se decelează ganglioni retroperitoneali, organe parenchimatoase omogene pre şi postcontrast, hepatosplenomegalie moderată. Reevaluarea echocardiografică pune în evidență o lamă minimă de lichid în pericard şi lamă de lichid în pleura dreaptă de $1,3 \mathrm{~cm}$; disfuncție diastolică biventriculară tip relaxare alterată şi funcție sistolică biventriculară normală.

Rezultatul provizoriu al examenului histopatologic a fost de Limfom limfoblastic cu celule $\mathrm{T}$, însă enzima TDT (terminal-deoxynucleotidil-transferază) specifică pentru limfocitele $\mathrm{T}$ din timus a ridicat suspiciunea unei alte patologii. Din acest motiv, pentru diagnosticul de certitudine blocul de parafină a fost trimis la Institutul Oncologic Budapesta - Departamentul de Anatomie Patologică. Între timp se iniţiază tratament citostatic (ALL ICBFM 2009), ulterior rezultatul final al examenului histopatologic este de Timom B3. După reevaluarea statusului pacientului, se iniţiază tratament citostatic conform protocolului VENUTA Tymom. În evoluție, la 2 luni după terminarea chimioterapiei a urmat radioterapie adjuvantă (DT 40 Grey/20fr.); la 4 luni de la finalizarea radioterapiei fără fixări patologice FDG (fludeoxiglucoza) la examinarea $\mathrm{PET} / \mathrm{CT}$; la bilanțul efectuat la 1 an se declară remisie clinică şi radiologică, ultimul examen PET/
CT la 1,9 ani de la finalizarea tratamentului fiind negativ.

\section{DISCUȚII}

Timomul şi carcinoamele timusului sunt tumori epiteliale ale timusului. La copii, tumorile timice reprezintă doar $2-3 \%$ din toate tumorile mediastinale, timomul fiind foarte $\operatorname{rar}(<1 \%)(5)$. O treime dintre pacienții cu timom sunt diagnosticați ca rezultat al unei anomalii pe o radiografie toracică, cum ar fi lărgirea mediastinului pe incidența anteroposterioară sau opacifierea retrosternală pe incidența laterolaterală (3). La cazul prezentat, radiografia toracică s-a efectuat datorită simptomelor respiratorii, suspicionându-se o tamponadă cardiacă. Însă examenul CT toracic sau RMN-ul poate dezvălui morfologia masei tumorale, prezența de chisturi sau necroză. În momentul efectuării examenului $\mathrm{CT}$, pacientul prezenta o masă solidă inomogenă, cu arii chistice la nivelul mediastinului anterior, înglobând timusul şi parţial structurile vasculare ale mediastinului mijlociu, cu amprentarea venei cave superioare. Deşi mai puţin frecvent, metastazele la distanță apar în 30-40\% dintre pacienții cu boală avansată $(3,6)$. Literatura de specialitate concluzionează că aproximativ 70\% dintre pacienții cu timom au simptomatologia altor boli, incluzând miastenia gravis (50\%), hipogamaglobulinemie $(5 \%)$, anemie aplastică $(5 \%)$, boli imune sau endocrinologice (10\%) (2). Pacientul prezentat mai sus nu a dezvoltat nici una dintre aceste patologii, singura manifestare a bolii fiind dată de compresia locală.

Rezecția chirurgicală reprezintă baza tratamentului pentru leziunile epiteliale ale timusului. Radioterapia şi chimioterapia sunt rezervate pentru tratamentul bolilor invazive şi maligne (5). Un studiu recent comparativ (153 de pacienți, Werneck et al) nu a găsit nici o diferență statistică între pacienții la care s-a efectuat timectomie şi cealaltă grupă de pacienți la care s-a optat pentru un tratament conservator (6). Fiind cu semne de tamponadă cardiacă şi compresie pe vena cavă superioară, în cazul pacientului nostru a fost necesară intervenţie chirurgicală de urgență în vederea decomprimării sistemului venos cav superior şi al segmentului arborelui respirator. Prognosticul acestor pacienți depinde de prezența sau absența metastazelor, de compresia traheală sau vasculară, exereza completă, tipul histologic epitelial, limfocitar sau mixt, dimensiunea tumorii mai mare de $8 \mathrm{~cm}(1)$. 


\section{CONCLUZII}

Deşi timomul este o tumoră rară, diagnosticul trebuie să fie luat în considerare în fața unei radiografii toracice cu un mediastin lărgit, asociată cu semne de compresie de venă cavă superioară şi simptome respiratorii. Invazia locoregională a tumorii, dar fără metastaze la distanță a condus la un răspuns favorabil la terapia citostatică, urmată de radioterapie. Prognosticul pacientului este unul favorabil, având în vedere ultimul bilanț clinic, paraclinic şi imagistic efectuat. 